\title{
Association between symptomatic vulvovaginal candidiasis and HIV RNA levels in plasma and genital secretions among women on HAART
}

T Apalata, ${ }^{1,2}$ MB ChB, MMed; W H Carr, ${ }^{3,4}$ DVM, PhD; B Longo-Mbenza, ${ }^{2} \mathrm{MD}$, PhD, DSc; W A Sturm, ${ }^{1} \mathrm{MD}, \mathrm{PhD}$;

P Moodley, ${ }^{1} \mathrm{MB} \mathrm{ChB}, \mathrm{MMed}, \mathrm{PhD}$

\author{
${ }^{1}$ Department of Medical Microbiology and Infection Prevention and Control, School of Laboratory Medicine and Medical Sciences, \\ College of Health Sciences, University of KwaZulu-Natal, Durban, South Africa \\ ${ }^{2}$ Department of Medical Microbiology, Faculty of Health Sciences, Walter Sisulu University, Mthatha, Eastern Cape, South Africa \\ ${ }^{3}$ HIV Pathogenesis Programme, Department of Paediatrics and Child Health, Nelson R Mandela School of Medicine, University of \\ KwaZulu-Natal, Durban, South Africa \\ ${ }^{4}$ Department of Biology, Medgar Evers College, The City University of New York, USA
}

Corresponding author: T Apalata(203520405@stu.ukzn.ac.za)

\begin{abstract}
Background. Genital tract (GT) inflammation plays a major role in HIV transmission. We aimed to determine the association between symptomatic vulvovaginal candidiasis (VVC) and HIV RNA levels in plasma and GTs of HIV-infected women on highly active antiretroviral therapy (HAART).

Method. Women with VVC on HAART were recruited from a primary healthcare clinic in KwaZulu-Natal Province, South Africa, between June 2011 and December 2011. VVC was diagnosed clinically, supported by Gram staining and culture of genital secretions. HIV RNA load was determined by reverse transcription polymerase chain reaction. $\mathrm{CD}^{+}$counts were obtained from patients' medical records.

Results. Plasma HIV RNA was detected in 42 of 60 (70\%) patients on HAART. The mean duration ( \pm standard deviation) on HAART for these patients was $4.2( \pm 1.6)$ months v. $10.7( \pm 1.4)$ months for the remaining 18 patients $(p<0.0001)$. Of the 42 women with detectable plasma HIV RNA, 12 (28.6\%) had detectable genital HIV RNA. Plasma HIV RNA levels ranged from $2.5( \pm 0.8)$ to $4.1( \pm 0.8) \log _{10}$ copies $/ \mathrm{ml}$. Genital HIV RNA levels ranged from 1.4 to $2.5( \pm 1.1) \log _{10}$ copies $/ \mathrm{ml}$. The adjusted odds ratios of plasma HIV RNA levels increased for patients $<35$ years $(p=0.039)$ and in those with VVC $(p=0.008)$. Detectability of HIV in genital secretions was significantly increased in patients with a plasma HIV load $\geq 10000 \mathrm{copies} / \mathrm{ml}(p=0.032)$ and genital absolute counts of neutrophils $>10$ cells/5 high microscopic fields $(p=0.007)$.

Conclusion. Given that the majority of women had recently initiated HAART (allowing a high rate of detectable plasma HIV RNA), there was insufficient evidence to conclude that VVC was predictive of high plasma HIV RNA levels. It is more likely that this cohort of immunosuppressed women were prone to develop VVC. Plasma HIV loads and local genital inflammation were predictors of genital HIV detectability.
\end{abstract}

S Afr J HIV Med 2014;15(2):57-64. DOI:10.7196/SAJHIVMED.975

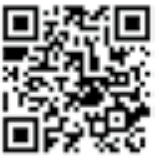

Ulcerative and non-ulcerative lower genital tract infections (LGTIs) are thought to play a major role in early HIV pathogenesis and transmission. ${ }^{[1]}$ LGTIs and plasma HIV viral load (VL) partially explain HIV shedding in the female genital tract (GT) ${ }^{[1,2]}$ Some studies have suggested that changes in the normal microbial flora of the female GT contribute to viral shedding. ${ }^{[1-3]}$

Conditions associated with genital inflammation, particularly genital ulcers, have been associated with HIV shedding in the $\mathrm{GT}^{[4,5]}$ While the association between non-ulcerative LGTIs such as bacterial vaginosis (BV) and GT HIV shedding has been well established, ${ }^{[6,7]}$ current studies have shown a less welldefined relationship between vulvovaginal candidiasis (VVC) and HIV shedding. In addition to BV that is not an established sexually transmitted infection (STI), vaginitis, an STI caused by Trichomonas vaginalis, has also been shown to increase the risk of HIV acquisition among women, ${ }^{[8,9]}$ and sexual and perinatal HIV transmission.

Data on the effect of highly active antiretroviral therapy (HAART) on vaginal infections among HIV-infected women are limited. Factors such as changes in vaginal immunological cell populations, cellular activation and cytokine production have been reported to alter susceptibility or response to genital infections. ${ }^{[10-13]}$ However, it remains unclear whether chemokines and cytokines interfere with the activity of polymorphonuclear neutrophil (PMN) cells and macrophages in the mucosa, or whether they facilitate the development of VVC. 


\section{Objective}

Our objective was to determine the association between symptomatic VVC and HIV RNA levels in the plasma and GTs of HIV-infected women on HAART. We hypothesised that in HIV-infected women, the presence of symptomatic VVC would affect local HIV shedding, but not systemic levels.

\section{Methods Study population}

For this cross-sectional study, consecutive adult ( $\geq 18$ years) women (all HIV-infected) attending Umlazi D clinic, a primary healthcare facility in KwaZulu-Natal (KZN) Province, South Africa, between June 2011 and December 2011 were enrolled after giving informed consent. Data on current symptoms suggestive of LGTIs were obtained by means of a standard questionnaire. Patients on HAART were defined as those receiving treatment with $\geq 2$ nucleoside reverse transcriptase inhibitors (NRTIs) and $\geq 1$ protease inhibitor (PI) or non-nucleoside reverse transcriptase inhibitor (NNRTI).

A physical examination was performed by the attending medical practitioner and signs of LGTIs were noted. Sixty paired plasma and cervicovaginal samples were collected from HIV-infected women receiving HAART. Patients aged $<18$ years and those who were menstruating or had visible blood contamination of genital samples were excluded from the study.

The study was approved by the Biomedical Research Ethics Committee of the University of KZN (Ref. BE 224/11). Consent forms were signed by all participants and confidentiality was maintained throughout the study.

\section{Collection and processing of cervico- vaginal fluid}

A vaginal tampon (8 Ks), Tampax Regular (Compak), was inserted into the vagina, left in situ for 3 minutes, and then placed in a sterile container containing $10 \mathrm{ml}$ of phosphate-buffered saline (Oxoid Ltd Basingstoke, UK) (pH 6.9). Samples were stored at $4^{\circ} \mathrm{C}$ for 4 hours prior to transport to the laboratory. Vaginal fluid was expressed using an autoclaved wooden tongue depressor and filtered through $0.22 \mu \mathrm{m}$ Costar Spin-X cellulose acetate filter membranes (Sigma). The filtered soluble fraction was aliquoted (in $1 \mathrm{ml}$ cryotubes) and stored at $-70^{\circ} \mathrm{C}$ until use.

\section{Measurement of absolute PMN cell counts from lower GT samples}

A vaginal swab (Becton Dickinson (BD)) was used to collect cells from the posterior fornix and to prepare a tissue smear on a glass slide for Gram staining. Absolute counts of neutrophils were determined by counting the total number of PMN cells in five randomly selected microscopic fields under oil immersion ( $\times 1000$ magnification) as previously described. The scores were as follows: score 1: 1- $10 \mathrm{PMN}$ cells/5 high microscopic fields (HMFs); score 2: 11 - $20 \mathrm{PMN}$ cells/5 HMFs; score 3: >20 PMN cells/5 HMFs. ${ }^{[14-16]}$

\section{Diagnostic criteria for symptomatic VVC and VVC colonisation}

The diagnosis of symptomatic VVC was based on a combination of clinical and laboratory criteria (evidence level III, recommendation grade B) ${ }^{[17-19]}$ Symptoms suggestive of VVC included vulval pruritus, vulval soreness, superficial dyspareunia, and/or non-offensive vaginal discharge. Signs included vulval erythema, vulval oedema, fissures, excoriation or thick curdy vaginal discharge.

A vaginal swab (BD) taken from the anterior fornix was directly plated onto Sabouraud Dextrose agar with chloramphenicol $\left(\mathrm{BBL}^{\mathrm{TM}}\right.$, $\mathrm{BD}$ ) and incubated at $29^{\circ} \mathrm{C}$ for 48 hours to estimate the relative vaginal fungal burden. The numbers of yeast colonies were recorded as the number of colonies per plate. ${ }^{[17-19]}$

In addition to the self-reported symptoms listed above and observation of signs suggestive of VVC on physical examination, cases of symptomatic VVC were confirmed if one of the following criteria was fulfilled (evidence level III, recommendation grade B): ${ }^{[17-19]}$ (i) a positive Gram-stain preparation with budding yeasts, pseudohyphae, and/or hyphal forms; and (ii) positive culture with either moderate (10 - 99 colonies per plate) or heavy (>100 colonies per plate) Candida growth.

Participants without symptomatic VVC were defined as: (i) patients whose genital specimens were negative for yeasts, pseudohyphae, and/ or hyphal forms of Candida on microscopy, together with negative culture; and (ii) patients whose genital specimens were negative for yeasts, pseudohyphae on microscopy, and/or hyphal forms of Candida together with light Candida growth $(<10$ colonies per plate). The latter was considered to indicate vaginal Candida colonisation rather than infection.

\section{Definitions of HIV-induced immunosuppression}

As part of the routine management and standard of care in the clinic, $\mathrm{CD}^{+} \mathrm{T}$-cell counts were measured in the blood of all HIV-infected patients. The $\mathrm{CD} 4^{+} \mathrm{T}$-cell counts used in this study were obtained from the past 3 months of measurements in patients' medical records. However, for the purpose of this research, HIV RNA was measured from the plasma and cell-free fraction of vaginal secretions using Nuclisens Easyq HIV-1 version 2.0 (BioMerieux, France) with a lowest detection limit of 20 copies $/ \mathrm{ml}^{\left[{ }^{[20-22]}\right.}$

Absolute values of $\mathrm{CD}^{+}{ }^{+} \mathrm{T}$-cell counts $($ cells/ $\mu \mathrm{l})$ were used to determine the degree or severity of immunosuppression as per the World Health Organization immunological staging criteria: severe immunosuppression $(<200 / \mu \mathrm{l})$; advanced immunosuppression (200

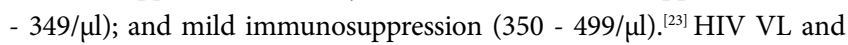
$\mathrm{CD}^{+}$counts were used as markers of disease progression. ${ }^{[23-25]}$ For the purpose of this study, plasma viraemia was classified as follows: $<20$ copies/ml (below detectable level of the test used); 20 - 9999 copies $/ \mathrm{ml}$; and $\geq 10000$ copies $/ \mathrm{ml}$. We also log-transformed HIV loads for improved symmetry and included them in multivariate logistic regression models as continuous values.

\section{Diagnosis of other LGTIs}

For each study participant, clinical symptoms and signs suggestive of LGTIs were recorded and categorised as absent, mild, moderate or severe. The diagnosis of BV was made using Nugent's scores. ${ }^{[15,16]} \mathrm{BD}$ nucleic acid amplification tests (BD Probetec Assays, Sparks) were performed on all cervical swabs to detect Chlamydia trachomatis and Neisseria gonorrhoeae. In addition, polymerase chain reaction amplifications of DNA isolated from vaginal swabs were performed as 
described previously to detect Mycoplasma genitalium, Trichomonas vaginalis and herpes simplex virus type $2 .^{[26,27]}$

\section{Statistical analyses}

Categorical variables were expressed as proportions (\%), and quantitative (discrete ordinal) variables were presented as mean $( \pm$ standard deviation). For univariate analyses, the $\chi^{2}$ test was used to compare proportions, while the $\mathrm{R}$ coefficient was computed to analyse the correlations between quantitative variables. Furthermore, univariate association between HIV RNA detectability (in plasma or vagina) and putative risk indicators was defined by odds ratios (ORs) with 95\% confidence intervals (CIs). For multivariate analyses, linear multiple and logistic regressions were used to identify independent determinants associated with HIV RNA detectability in the vagina or plasma. Multivariate ORs $(95 \%$ CI) of HIV RNA genital/plasma detectability were computed after adjusting for confounding factors. Excess risks were measured using the risk difference method.

All tests were two-sided and $p<0.05$ was considered significant. Data were analysed using SPSS ${ }^{\circ}$ statistical software version 21.0 (SPSS Inc., Chicago, USA).

\section{Results}

The median age of the 60 women enrolled in the study was 30 years (range 18 - 46). All were black Africans.

Plasma HIV RNA was detected in 42 (70\%) patients. The mean duration on HAART was $4.2( \pm 1.6)$ months for patients with detectable plasma HIV RNA (CD4+ ${ }^{+}$T-cell count $<350$ cells $/ \mu \mathrm{l})$ while for the remaining 18 patients $\left(\mathrm{CD} 4^{+} \mathrm{T}\right.$-cell count $\geq 350$ cells $\left./ \mu \mathrm{l}\right)$ it was $10.7( \pm 1.4)$ months $(p<0.0001)$.

Of the 42 women with detectable plasma HIV RNA, 12 (28.6\%) had detectable genital HIV RNA. Only one patient had detectable genital
HIV RNA in the absence of detectable plasma HIV RNA. Plasma HIV RNA levels ranged from $2.5( \pm 0.8) \log _{10}$ copies/ml to $4.1( \pm 0.8)$ $\log _{10}$ copies/ml. Genital HIV RNA levels ranged from $1.4 \log _{10}$ copies/ml to $2.5( \pm 1.1) \log _{10}$ copies $/ \mathrm{ml}$ (Table 1). Eight patients out of 12 (66.7\%) with detectable genital HIV RNA had plasma HIV loads $>10000$ copies $/ \mathrm{ml}$, while the remaining patients had plasma HIV loads of between 20 and 9999 copies/ml. Fig. 1 shows the distribution of plasma HIV loads and genital HIV RNA detectability according to duration of HAART.

All patients were on HAART regimen 1, namely two NRTIs and one NNRTI. No patient received PIs.
The univariate analysis (Table 2) showed a significant association between symptomatic VVC and plasma HIV RNA detectability $(p=0.006)$, and patients who complained of symptoms suggestive of symptomatic VVC had significantly increased plasma HIV RNA levels $(p=0.039)$. In addition, a recent history (within the past 3 months) of STIs ( $p=0.035$ ) and patients age $<35$ years $(p=0.018)$ were also significantly associated with detectable HIV RNA in the plasma. Furthermore, the presence of both advanced and severe HIV-associated immunosupression was significantly associated with HIV RNA detectability in the plasma $(p<0.0001)$. In contrast, no patient with a $\mathrm{CD} 4{ }^{+} \mathrm{T}$-cell count

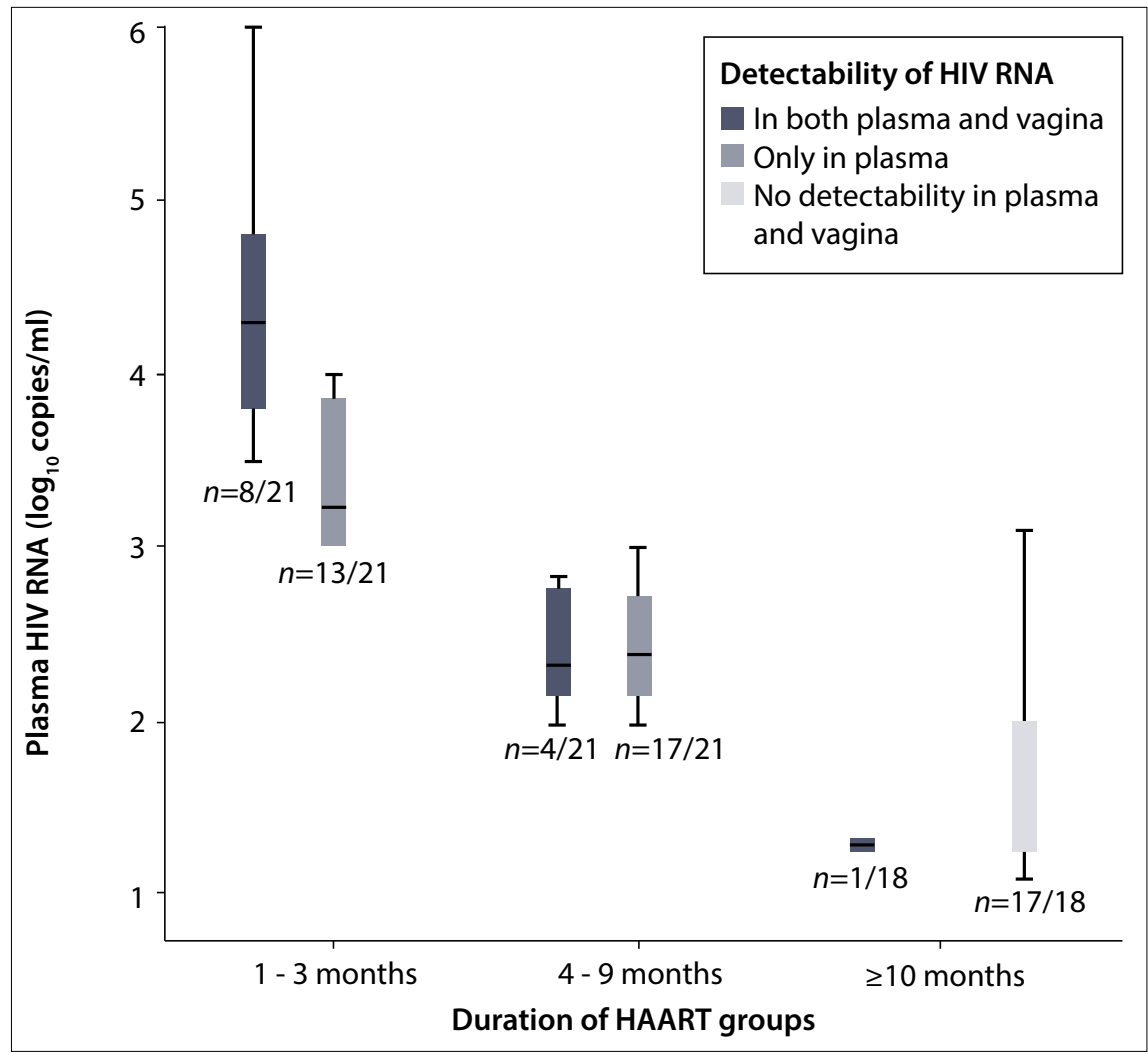

Fig. 1. Distribution of plasma HIV loads and genital HIV RNA detectability among HAART recipients $(\mathrm{n}=60)$. (HAART = highly active antiretroviral therapy.)

Table 1. HIV RNA levels in plasma and GT by HAART duration $(N=60)$

\begin{tabular}{|c|c|c|c|}
\hline HAART duration (months) & Patient groups $(n)$ & $\begin{array}{l}\text { VL in plasma }\left(\log _{10} \text { copies } / \mathrm{ml}\right) \\
\text { mean }( \pm \mathrm{SD})^{\star}\end{array}$ & $\begin{array}{l}\text { VL in vagina }\left(\log _{10} \text { copies } / \mathrm{ml}\right) \\
\text { mean }( \pm S D)^{*}\end{array}$ \\
\hline \multirow[t]{2}{*}{$0-3$} & $1 \mathrm{~A}(n=8 / 21)$ & $4.1( \pm 0.8)$ & $2.5( \pm 1.1)$ \\
\hline & $1 \mathrm{~B}(n=13 / 21)$ & $3.3( \pm 1.4)$ & $<1.3$ (not detectable) \\
\hline \multirow[t]{2}{*}{$4-9$} & $2 \mathrm{~A}(n=4 / 21)$ & $2.5( \pm 0.9)$ & $1.6( \pm 0.5)$ \\
\hline & $2 \mathrm{~B}(n=17 / 21)$ & $2.9( \pm 1.1)$ & $<1.3$ (not detectable) \\
\hline \multirow[t]{2}{*}{$\geq 10$} & $3 \mathrm{~A}(n=1 / 18)$ & $<1.3$ (not detectable) & 1.4 \\
\hline & $3 \mathrm{~B}(n=17 / 18)$ & $<1.3$ (not detectable) & $<1.3$ (not detectable) \\
\hline
\end{tabular}


Table 2. Univariate analysis of factors associated with plasma HIV RNA levels in HIV-positive women receiving HAART $(N=60)$

\begin{tabular}{|c|c|c|}
\hline Associated factors & $\begin{array}{l}\text { Detectable plasma } \\
\text { HIV RNA, } n(\%)\end{array}$ & $p$-value \\
\hline Age groups (years) & & 0.018 \\
\hline $18-24$ & $11(84.6)$ & \\
\hline $25-34$ & $25(75.8)$ & \\
\hline$\geq 35$ & $6(42.9)$ & \\
\hline $\begin{array}{l}\text { Symptomatic VVC } \\
(\text { OR } 6.1,95 \% \text { CI } 1.5-24.1)\end{array}$ & & 0.006 \\
\hline Yes & $23(88.5)$ & \\
\hline No & $19(55.9)$ & \\
\hline $\begin{array}{l}\text { Presenting complaints } \\
\text { (OR 5.7, 95\% CI } 0.9 \text { - 34.7) }\end{array}$ & & 0.039 \\
\hline $\begin{array}{l}\text { Group } 1 \text { (vulval itching, soreness } \\
\text { and discharge) }\end{array}$ & $40(74.1)$ & \\
\hline $\begin{array}{l}\text { Group } 2 \text { (lower abdominal pain, vaginal } \\
\text { discharge) }\end{array}$ & $2(33.3)$ & \\
\hline Recent history (past 3 months) of STIs & & 0.035 \\
\hline Vaginal discharge syndrome & $26(78.8)$ & \\
\hline Genital ulcer syndrome & $6(85.7)$ & \\
\hline No STI diagnosed & $10(50.0)$ & \\
\hline $\mathrm{CD}^{+}{ }^{+} \mathrm{T}$-cell count $($ cells $/ \mu \mathrm{l})$ & & $<0.0001$ \\
\hline$<200$ & $22(100)$ & \\
\hline $200-349$ & $20(100)$ & \\
\hline$\geq 350$ & $0(0)$ & \\
\hline Genital HIV load categories (copies/ml) & & 0.062 \\
\hline$\geq 10000$ & $2(100)$ & \\
\hline $20-9999$ & $10(90.0)$ & \\
\hline$<20$ & $30(65.2)$ & \\
\hline Genital absolute neutrophil counts & & 0.095 \\
\hline$>20$ cells $/ 5$ HMFs & $12(60.0)$ & \\
\hline $11-20$ cells/5 HMFs & $13(92.9)$ & \\
\hline $1-10$ cells/5 HMFs & $17(65.4)$ & \\
\hline
\end{tabular}

$\geq 350$ cells $/ \mu$ l had detectable plasma HIV RNA.

In the multivariate analysis (Table 3), logistic regression was used to identify independent determinants of HIV RNA levels in plasma after adjusting for univariate confounding factors (presenting complaints and recent history of STIs). CD4 ${ }^{+}$T-cell counts were not included in the logistic regression model because all patients with detectable plasma HIV RNA had either advanced or severe immunosupression.

Multivariate analysis showed that a current episode of symptomatic VVC was independently $(p=0.008)$ associated with detectable HIV RNA in the plasma. It was also found that HIV-infected women aged $<35$ years were more likely to have higher HIV RNA levels in their plasma than women aged $\geq 35$ years $(p=0.039)$ (Table 3).

\section{Factors associated with genital HIV RNA shedding}

Of the 42 women with detectable plasma HIV RNA, 12 (28.6\%) had detectable levels of HIV RNA in cell-free vaginal fluid.

Table 4 shows univariate factors associated with genital HIV RNA detectability among the patients. Women with a recent history of vaginal discharge syndrome $(p=0.05)$ and genital ulcer syndrome $(p=0.038)$ were more likely to have detectable HIV RNA in their GTs (Table 4). However, the data showed no association between gonococcus, VVC or BV and genital HIV shedding.

Women with a neutrophil cell count score of $>1$ had a five-fold higher risk (OR 5.3, 95\% CI 1.6 - 17.2; $p=0.004$ ) of having detectable HIV RNA in their GTs than women with a neutrophil cell count score of 1 . A recent history of use of broad-spectrum antimicrobial agents was shown to be associated with

Table 3. Independent determinants of plasma HIV RNA levels in HIV-infected women receiving HAART $(\mathbf{N}=\mathbf{6 0})$

\begin{tabular}{|c|c|c|c|c|c|}
\hline Independent variables & $\beta$-coefficient & Standard error & Wald $\chi^{2}$ & OR $(95 \% \mathrm{CI})$ & $p$-value \\
\hline Age groups (years) & & & & & 0.039 \\
\hline $18-24$ & 2.328 & 1.043 & 4.978 & $10.3(1.3-79.2)$ & 0.026 \\
\hline $25-34$ & 1.765 & 0.789 & 5.001 & $5.8(1.2-27.5)$ & 0.025 \\
\hline$\geq 35$ & & & Reference & 1 & \\
\hline \multicolumn{6}{|l|}{ Symptomatic VVC } \\
\hline Yes & 2.082 & 0.790 & 6.943 & $8(1.7-37.7)$ & 0.008 \\
\hline No & & & Reference & 1 & \\
\hline Constant & -1.236 & 0.719 & 2.954 & & 0.086 \\
\hline
\end{tabular}




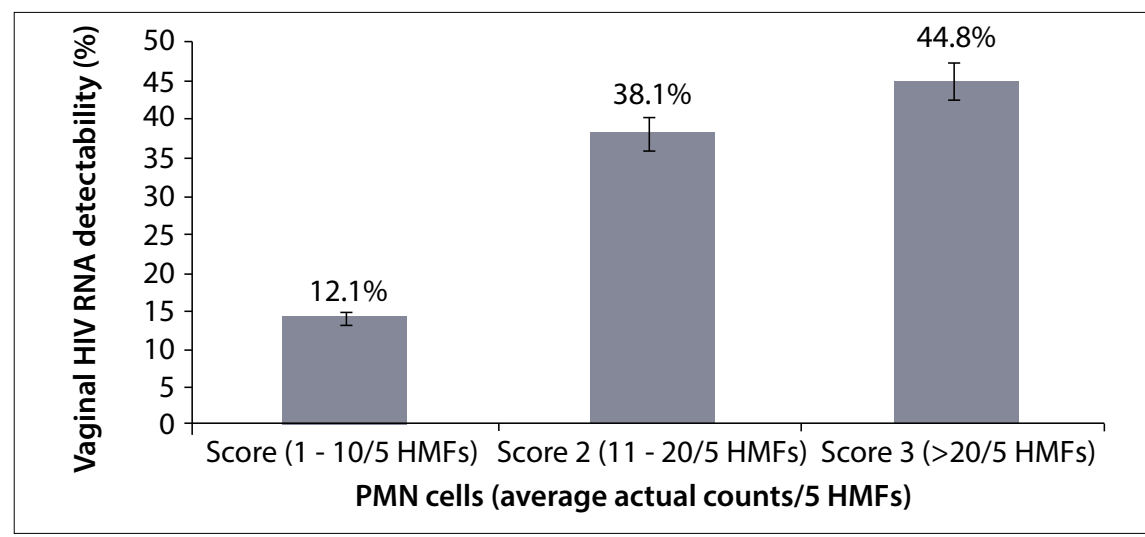

Fig. 2. Distribution of vaginal HIV RNA detectability by $P M N$ cell groups $(\mathrm{p}=0.005)$. ( $P M N=$ polymorphonuclear neutrophil; HMFs = high microscopic fields.)

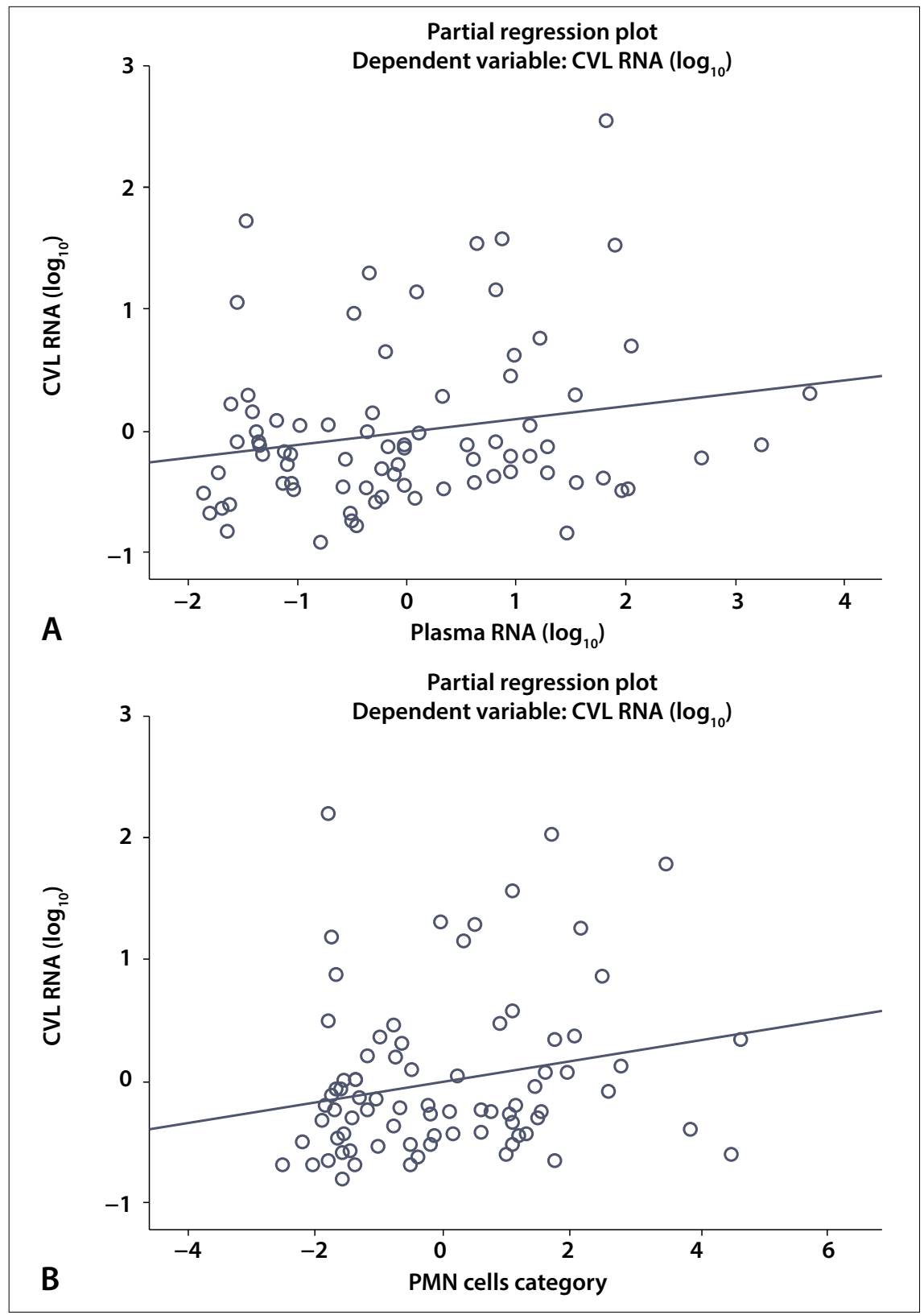

Fig. 3. Variation of genital HIV RNA levels as predicted by ( $A$ ) plasma HIVloads $\left(r=0.2, R^{2}=0.04 ; p=0.032\right)$ and $(B)$ genital $P M N$ cells $\left(r=0.21, R^{2}=0.045 ; p=0.007\right)$. (CVL = cervicovaginal lavage; $P M N=$ polymorphonuclear neutrophil.) detectable HIV shedding in the univariate analysis $(p=0.048)$ (Table 4$)$.

In the multivariate analysis, after adjusting for the presence of univariate confounding factors (use of broad-spectrum antibiotics and recent history of STIs), an increase in the vaginal absolute neutrophil counts $(p=0.007)$ and plasma HIV RNA levels $(\mathrm{p}=0.032)$ remained independently associated with genital HIV shedding $(p=0.005)$ (Table 5; Fig. 3). Plasma VL (20 - 9999 copies $/ \mathrm{ml}$ ) tended to correlate positively with genital HIV shedding, but this correlation did not reach statistical significance $(p=0.166)$. However, plasma HIV RNA levels $\geq 10000$ copies $/ \mathrm{ml}$ $(p=0.032)$ were independently associated with genital HIV RNA detectability to a detection limit of 20 copies/ml (Table 5).

Furthermore, when using transformed $\log _{10}$ HIV RNA values, correlations between plasma HIV RNA levels and genital PMN cell counts $>10$ cells/5 HMFs with detectability of genital HIV RNA shedding showed significant associations (Fig. 3). Detectability and levels of mean $\log _{10}$ HIV RNA in the vaginal fluid increased with the increase of plasma HIV RNA levels $\left(\log _{10}\right)\left(r=0.2, R^{2}=0.04 ; p=0.032\right)$ (Fig. 3A) and increased absolute counts of genital PMN cells $\left(r=0.21, R^{2}=0.045 ; p=0.007\right)$ (Fig. 3B).

\section{Discussion}

Inflammation of the GT during LGTIs, particularly STIs and BV, has been reported to predict increased plasma VLs in HIVinfected women. ${ }^{[28,29]}$ In this study, given that the majority of women had just initiated HAART (and therefore had a high rate of detectable plasma HIV RNA and low CD4 counts), there was insufficient evidence to demonstrate that VVC was predictive of high plasma HIV RNA levels. Although cause and effect was difficult to unravel in the current study design, it seemed more likely that the observed higher level of immunosuppression among the study participants influenced the occurrence of VVC. In addition, plasma HIV loads and local genital inflammation were predictors of genital HIV shedding, but did not predict the presence of VVC. Women aged $<35$ years were more likely to have increased plasma HIV RNA levels than women aged $\geq 35$ years. A previous study of the relationship between age and plasma VL in HIV-infected individuals showed that older ages ( $>50$ years) compared with individuals aged 18 - 39 years were associated with lower levels of HIV-1 replication. ${ }^{[30]}$ This finding was independent of 
antiretroviral therapy use, regimen adherence and disease stage. One possible explanation of the relationship between the plasma VL

and age category would be immunological differences. It has been shown that older age was associated with an increase in peripheral
Table 4. Univariate analysis of factors associated with genital HIV RNA detectability in HIV-infected women receiving HAART $(\boldsymbol{N}=60)$

\begin{tabular}{|c|c|c|c|}
\hline Associated factors & $\begin{array}{l}\text { Detectable } \\
\text { genital HIV } \\
\text { RNA } n(\%)\end{array}$ & OR $(95 \% \mathrm{CI})$ & $p$-value \\
\hline \multicolumn{4}{|l|}{ Current STIs } \\
\hline Trichomonas vaginalis & & $0.7(0.3-2.1)$ & 0.554 \\
\hline Positive & $6(25.0)$ & & \\
\hline Negative & $18(31.6)$ & & \\
\hline Chlamydia trachomatis & & $0.8(0.2-2.9)$ & 0.781 \\
\hline Positive & $4(26.7)$ & & \\
\hline Negative & $20(30.3)$ & & \\
\hline Neisseria gonorrhoeae & & $1.2(0.3-5.3)$ & 0.796 \\
\hline Positive & $3(33.3)$ & & \\
\hline Negative & $21(29.2)$ & & \\
\hline Mycoplasma genitalium & & $0.5(0.1-4.1)$ & 0.478 \\
\hline Positive & $1(16.7)$ & & \\
\hline Negative & $23(30.7)$ & & \\
\hline Herpes simplex virus type 2 & & $0.7(0.6-0.8)$ & 0.183 \\
\hline Positive & $0(0)$ & & \\
\hline Negative & $24(31.2)$ & & \\
\hline \multicolumn{4}{|l|}{ Other lower GT infections } \\
\hline VVC & & $1.2(0.5-3.2)$ & 0.649 \\
\hline Infection & $13(32.5)$ & & \\
\hline Colonisation & $12(27.9)$ & & \\
\hline BV & & $1.2(0.4-4.3)$ & 0.747 \\
\hline Positive & $21(30.9)$ & & \\
\hline Negative & $4(26.7)$ & & \\
\hline \multicolumn{4}{|l|}{$\begin{array}{l}\text { Recent history (past } 3 \text { months) of } \\
\text { STIs }\end{array}$} \\
\hline Vaginal discharge syndrome & $14(36.8)$ & $3.2(1.0-10.1)$ & 0.050 \\
\hline Genital ulcer syndrome & $6(46.2)$ & $4.6(1.1-19.7)$ & 0.038 \\
\hline No STI & $5(15.6)$ & 1 & \\
\hline Genital absolute neutrophil counts & & $5.3(1.6-17.2)$ & 0.004 \\
\hline Score $>1$ & $21(42.0)$ & & \\
\hline Score $=1$ & $4(12.1)$ & & \\
\hline Plasma HIV RNA levels & & & $<0.0001$ \\
\hline$\geq 10000$ copies $/ \mathrm{ml}\left(\geq 4 \log _{10}\right)$ & $8(100)$ & & \\
\hline $\begin{array}{l}20-9999 \text { copies } / \mathrm{ml}\left(1.3 \log _{10}-\right. \\
\left.3.99 \log _{10}\right)\end{array}$ & $4(11.8)$ & & \\
\hline$<20$ copies $/ \mathrm{ml}\left(<1.3 \log _{10}\right)$ & $1(5.6)$ & & \\
\hline Antibiotic use & & $3.2(1.01-10.60)$ & 0.048 \\
\hline Yes & $21(36.8)$ & & \\
\hline No & $4(15.4)$ & & \\
\hline
\end{tabular}

HAART = highly active antiretroviral therapy; $\mathrm{OR}=$ odds ratio; $\mathrm{CI}$ = confidence interval; STIs = sexually transmitted infections; $\mathrm{GT}=$ genital tract; $\mathrm{VVC}=$ vulvovaginal candidiasis; $\mathrm{BV}=$ bacterial vaginosis.
$\mathrm{CD} 4^{+}$and $\mathrm{CD} 8^{+} \mathrm{T}$ lymphocytes and that thymic involution was associated with this effect, leading to lower expression of plasma HIV-1 RNA. ${ }^{[30]}$

Studies of the association between HIV VL in the female GT and in the plasma have shown conflicting results. In this study, $28.6 \%$ of the patients shed HIV in their genital secretions. This finding is consistent with previous reports of HIV-1 DNA and/or RNA being detected in the GT of $28-60 \%$ of HIV1-seropositive women. ${ }^{[29,31-33]}$ These previous studies also demonstrated that genital HIV-1 was more likely to be detected from either the cell-associated fraction of the cervicovaginal fluid or whole genital fluid than from cellfree vaginal fluid. ${ }^{[29,31-33]}$ Although within the published range, our finding of a relatively low frequency of viraemia in the GT of our study population may be attributed to the type of sample that was analysed (measurement of HIV loads in cell-free fraction alone). It is difficult to conclude that antiretroviral therapy significantly lowered HIV RNA levels in genital secretions, given the fact that the women had just started HAART.

We found that women with a recent history of vaginal discharge syndrome and genital ulcer syndrome were more likely to shed HIV in their GTs than women without a recent history of such STIs. However, after testing for the most common causes of LGTIs, none of the tested aetiological agents of vaginal discharge syndrome (VDS) showed significant association with genital HIV shedding.

The fact that HIV VL was only measured from the cell-free fraction of genital secretions may account for the lack of an association between GT viraemia and tested causes of VDS, including symptomatic VVC.

We identified two independent factors associated with HIV RNA shedding in the vagina; of these factors, one had been previously identified, namely the association between higher levels of plasma HIV RNA and the ability to detect HIV in genital secretions. ${ }^{[31,34]}$ Consistent with previous studies, we found that genital HIV RNA detectability strongly correlated with plasma HIV VL, but that these correlations were weak, except when plasma HIV VL was $\geq 10000$ copies $/ \mathrm{ml}$. Other studies have suggested that compartmentalisation of the vaginal immune response from systemic immunity may account for such weak correlations. ${ }^{[35,36]}$ This might also be explained by the fact that HIV VL was only measured from the cell-free fraction of the genital secretions. 
Table 5. Independent determinants of HIV RNA detectability in GT of HIV-infected women receiving HAART $(N=60)$

\begin{tabular}{|c|c|c|c|c|c|}
\hline Independent variables & $\beta$-coefficient & Standard error & Wald $\chi^{2}$ & OR $(95 \% \mathrm{CI})$ & $p$-value \\
\hline \multicolumn{6}{|l|}{$\begin{array}{l}\text { Plasma HIV RNA } \\
\text { (copies/ml) }\end{array}$} \\
\hline$\geq 10000$ & 2.062 & 0.962 & 4.593 & $7.9(1.2-51.8)$ & 0.032 \\
\hline $20-9999$ & 1.168 & 0.843 & 1.918 & $3.2(0.6-16.8)$ & 0.166 \\
\hline$<20$ & & & Reference & 1 & \\
\hline \multicolumn{6}{|l|}{ Vaginal PMN cells } \\
\hline Score $>1$ & 1.758 & 0.650 & 7.308 & $5.8(1.6-20.8)$ & 0.007 \\
\hline Score $=1$ & & & Reference & 1 & \\
\hline Constant & -1.123 & 0.518 & 2.980 & & 0.005 \\
\hline
\end{tabular}

We also found that the absolute neutrophil count in the genital mucosa was another factor associated with genital HIV RNA shedding. Previous studies have shown the role of genital inflammation in HIV-1 shedding. ${ }^{[8,37]}$ It has been reported that following HIV-1 infection, cytokines and chemokines are produced by infected leukocytes that attract more target cells for HIV-1 infection and allow further stimulation of the expression of HIV-1 via toll-like receptors. ${ }^{[8-10]}$ In this study, we found that the number of neutrophils in the female GT was associated with HIV shedding. Of particular interest, our study did not show an association between symptomatic VVC and HIV shedding in the vagina. In addition to the fact that HIV was quantified only in the cell-free fraction of genital fluids, this lack of association could also be the result of strong recruitment of neutrophils in the vagina - various immunomodulators have been reported as associated with the antiCandida activity of neutrophils. ${ }^{[35,36]}$ Cytokines such as TNF- $\alpha$ and IL-8 increase the activity of neutrophils against Candida albicans. ${ }^{[35]}$ Gumbi et al. ${ }^{\left[{ }^{[36]}\right.}$ reported that women who were detectably shedding HIV-1 in the GT had significantly increased cervical levels of TNF- $\alpha$, IL- $1 \beta$, IL- 6 and IL- 8 compared with women who were not detectably shedding the virus. It remains unclear from our observations whether or not symptomatic VVC is more likely to occur among HIV-infected women who are not detectably shedding the virus.

Another possible reason why symptomatic VVC was not associated with genital HIV shedding could be the challenges associated with the diagnosis of VVC. A clinical definition of VVC could be problematic even when microscopic tests and cultures of genital samples are used to support the clinical diagnosis. While Gram staining has a sensitivity of $75 \%$ in supporting the clinical diagnosis of VVC, up to $30 \%$ of women with significant chronic symptoms suggestive of VVC may have negative cultures at presentation. ${ }^{[38]}$

\section{Limitations}

Limitations of this study include its cross-sectional design and small sample size. In addition, the impact of factors such as HAART regimen composition, adherence to HAART and effects of HIV disease stages were not explored.

The majority of our patients had just started HAART. Therefore, it is difficult to say that they were not successfully treated. A plausible hypothesis for why we did not find an association between VVC and genital HIV shedding could have been the fact that HIV RNA was only measured from the cell-free fraction of cervicovaginal secretions. If both HIV complementary DNA and HIV RNA had been measured, results could have been different. This might also explain why plasma HIV loads $<10000$ copies/ml were not significantly associated with genital HIV shedding in the multivariate logistic analysis.

Finally, findings present insufficient evidence of the true impact of VVC on HIV RNA levels in plasma and genital secretions.

\section{Conclusions}

Identified factors associated with HIV RNA loads in plasma and female genital secretions were consistent with previously published factors from the literature. Of particular note, our study did not have enough evidence to demonstrate that symptomatic VVC was predictive of higher levels of HIV RNA in plasma and genital secretions. However, unlike STIs and BV, symptomatic VVC was less likely to occur among HIV-infected women who were detectably shedding the virus in their lower GT, possibly owing to the observed strong recruitment of neutrophils that possess anti-Candida activity or the challenges associated with the diagnosis of VVC. About $70 \%$ of the study population had detectable HIV RNA in their plasma; this finding was supported by the fact that all these patients had a $\mathrm{CD} 4^{+} \mathrm{T}$-cell count $<350$ cells $/ \mu$ l, which is a marker of systemic immunosuppression. It is highly likely that the observed higher rate of HIV RNA detectability was purely the result of immunosuppression and that the associated high prevalence of symptomatic VVC could have been a consequence of overall immunosuppression. Further studies are required to ascertain the impact of VVC on HIV RNA levels in plasma and genital secretions.

Acknowledgments. We are grateful to the Hasso Plattner Foundation, the National Research Foundation and the National Institutes of Health for partially funding this study by means of grants to T Apalata, P Moodley and W H Carr, respectively.

\section{References}

1. Coetzee D, Johnson L. Sexually transmitted infections. In: Karim ASS, Karim AQ eds. HIV/AIDS in South Africa. Cape Town: Cambridge University Press, 2010:219220. [http://dx.doi.org/10.1017/CBO9781139062404.014]

2. Plummer FA. Heterosexual transmission of human immunodeficiency virus type 1 (HIV): Interactions of conventional sexually transmitted diseases, hormonal contraception and HIV-1. AIDS Res Hum Retroviruses 1998;14(1):S5-S10.

3. Sobel JD. Vulvovaginal candidiasis. Lancet 2007;369(9577):1961-1971. [http://dx.doi. org/10.1016/S0140-6736(07)60917-9] 
4. Miller CJ, Shattock RJ. Target cells in vaginal HIV transmission. J Microbes Infect 2003;5(1):59-67. [http://dx.doi.org/10.1016/S1286-4579(02)00056-4]

5. Anderson BL, Wang CC, Delong AK, et al. Genital tract leukocytes and shedding of genital HIV type-1 RNA. Clin Infect Dis 2008;47(9):1216-1221. [http://dx.doi org/10.1086/592303

6. Cu-Uvin S, Hogan JW, Caliendo AM, Harwell J, Mayer KH, Carpenter CC Association between bacterial vaginosis and expression of human immunodeficiency virus type 1 RNA in the female genital tract. Clin Infect Dis 2001;33(6):894-896. [http://dx.doi.org/10.1086/322613]

7. Sha BE, Zariffard MR, Wang QJ, et al. Female genital-tract HIV load correlates inversely with Lactobacillus species but positively with bacterial vaginosis and Mycoplasma hominis. J Infect Dis 2005;191(1):25-32. [http://dx.doi.org/10.1086/426394]

8. Martin HL, Richardson BA, Nyange PM, et al. Vaginal lactobacilli, microbial flora and risk of human immunodeficiency virus type 1 and sexually transmitted disease acquisition. J Infect Dis 1999;180(6):1863-1868. [http://dx.doi.org/10.1086/315127]

9. Sorvillo F, Kovacs A, Kerndt P, Stek A, Muderspach L, Sanchez-Keeland L. Risk factors for trichomoniasis among women with human immunodeficiency virus infection at a public clinic in Los Angeles County, California: Implications for HIV prevention. Am J Trop Med Hyg 1998;58(4):495-500.

10. Warren D, Klein RS, Sobel J, et al. A multicenter study of bacterial vaginosis in women with or at risk for human immunodeficiency virus infection. Infect Dis Obstet Gynecol 2001;9(3):133-141. [http://dx.doi.org/10.1155/S1064744901000242]

11. Duerr A, Heilig CM, Meikle SF, et al.; HER Study Group. Incident and persisten vulvovaginal candidiasis among human immunodeficiency virus-infected women: Risk factors and severity. Obstet Gynecol 2003;101(3):548-556. [http://dx.doi. org/10.1016/S0029-7844(02)02729-1]

12. Jamieson DJ, Duerr A, Klein RS, et al. Longitudinal analysis of bacterial vaginosis: Findings from the HIV epidemiology research study. Obstet Gynecol 2001;98(4):656663. [http://dx.doi.org/10.1016/S0029-7844(01)01525-3]

13. Barousse MM, Van Der Pol BJ, Fortenberry D, Orr D, Fidel PL Jr. Vaginal yeast colonization, prevalence of vaginitis, and associated local immunity in adolescents. Sex Transm Infect 2004;80(1):48-53. [http://dx.doi.org/10.1136/sti.2002.003855]

14. Hitti J, Hillier SL, Agnew KJ, Krohn MA, Reisner DP, Eschenbach DA. Vagina indicators of amniotic fluid infection in preterm labor. Obstet Gynecol 2001;97(2):211-219. [http://dx.doi.org/10.1016/S0029-7844(00)01146-7]

15. Cauci S, Guaschino S, Driussi S, De Santo D, Lanzafame P, Quadrifoglio F. Correlation of local interleukin-8 with immunoglobulin A against hemolysin and with prolidase and sialidase levels in women with bacterial vaginosis. J Infect Dis 2002;185(11):1614-1620. [http://dx.doi.org/10.1086/340417]

16. Cauci S, Guaschino S, De Aloysio D, et al. Interrelationships of interleukin-8 with interleukin- $\mathrm{lb}$ and neutrophils in vaginal fluid of healthy and bacterial vaginosis positive women. Mol Hum Reprod 2003;9(1):53-58. [http://dx.doi.org/10.1093/molehr/gag003]

17. Sonnex C, Lefort W. Microscopic features of vaginal candidiasis and their relation to symptomatology. Sex Transm Infect 1999;75(6):417-419. [http://dx.doi.org/10.1136/ sti.75.6.417]

18. Eckert LO, Hawes SE, Stevens CE, Koutsky LA, Eschenbach DA, Holmes KK Vulvovaginal candidiasis: Clinical manifestations, risk factors, managemen algorithm. Obstet Gynecol 1998;92(5):757-765. [http://dx.doi.org/10.1016/S00297844(98)00264-6]

19. Abbott J. Clinical and microscopic diagnosis of vaginal yeast infection: A prospective analysis. Ann Emerg Med 1995;25(5):587-591. [http://dx.doi.org/10.1016/S01960644(95)70168-0]

20. de Mendoza C, Soriano V. Update on HIV viral-load assays: New technologies and testing in resource-limited settings. Future Virol 2009;4(5):423-430. [http://dx.doi. org/10.2217/fvl.09.24]
21. Gomes P, Carvalho AP, Diogo I, et al. Comparison of the NucliSENS EasyQ HIV1 v2.0 with Abbott m2000rt RealTime HIV-1 assay for plasma RNA quantitation in different HIV-1 subtypes. J Virol Methods 2013;193(1):18-22. [http://dx.doi. org/10.1016/j.jviromet.2013.05.001]

22. Kébé $\mathrm{K}$, Ndiaye $\mathrm{O}$, Diop Ndiaye $\mathrm{H}$, et al. RNA versus DNA (NucliSENS EasyQ HIV-1 v1.2 versus Amplicor HIV-1 DNA Test v1.5) for early diagnosis of HIV-1 infection in infants in Senegal. J Clinical Microbiol 2011;49(7):2590-2593. [http:// dx.doi.org/10.1128/JCM.02402-10]

23. World Health Organization. Interim WHO clinical staging of HIV/AIDS and HIV/ AIDS case definitions for surveillance. Geneva: World Health Organization, 2005.

24. Coombs R, Collier A, Allain J, et al. Plasma viremia in human immunodeficiency virus infection. N Engl J Med 1989;321:1626-1631. [http://dx.doi.org/10.1056/ NEJM198912143212402]

25. Ho D, Moudgil T, Alam M. Quantitation of human immunodeficiency virus type 1 in the blood of infected persons. N Engl J Med1989;321(24):1621-1625. [http:// dx.doi.org/10.1056/NEJM198912143212401]

26. Zimba TF, Apalata T, Sturm AW, Moodley P. Aetiology of sexually transmitted infections in Maputo, Mozambique. J Infect Dev Ctries 2011;5(1):41-47.

27. Apalata T, Zimba TF, Sturm AW, Moodley P. Antimicrobial susceptibility profile of Neisseria gonorrhoeae isolated from patients attending a STD facility in Maputo, Mozambique. Sex Transm Dis 2009;36(6):341-343. [http://dx.doi.org/10.1097/ OLQ.0b013e3181982e3c]

28. Roberts L, Passmore JAS, Mlisana K, et al. Genital tract inflammation during early HIV-1 infection predicts higher plasma viral load set point in women. J infect Dis 2011:205(2):194-203. [http://dx.doi.org/10.1093/infdis/jir715]

29. Goulston C, McFarland W, Katzenstein D. Human immunodeficiency virus type 1 RNA shedding in the female genital tract. J Infect Dis 1998;177(4):1100-1103. [http://dx.doi.org/10.1086/517404]

30. Goodkin K, Shapshak P, Asthana D, et al. Older age and plasma viral load in HIV-1 infection. AIDS 2004;18(Suppl 1):S87-S98. [http://dx.doi.org/10.1097/00002030200401001-00013]

31. Uvin SC, Caliendo AM. Cervicovaginal human immunodeficiency virus secretion and plasma viral load in human immunodeficiency virus-seropositive women. Obstet Gynecol 1997;90(5):739-743. [http://dx.doi.org/10.1016/S0029-7844(97)00411-0]

32. Mostad SB. Prevalence and correlates of HIV type 1 shedding in the female genital tract. AIDS Res Hum Retroviruses 1998;14(Suppl 1):S11-S15.

33. Henin Y, Mandelbrot L, Henrion R, Pradinaud R, Coulaud JP, Montagnier L. Virus excretion in the cervicovaginal secretions of pregnant and nonpregnant HIVinfected women. J Acquir Immune Defic Syndr 1993;6(1):72-75.

34. Shacklett BL. Mucosal immunity to HIV: A review of recent literature. Curr Opin HIV/AIDS 2008;3(5):541-547. [http://dx.doi.org/10.1097/COH.0b013e32830ab9ee]

35. Fidel PL Jr. Innate and adaptive cell-mediated immunity against vaginal candidiasis. Fungal Immunology 2005;5:323-344. [http://dx.doi.org/10.1007/0-387-25445-5_16]

36. Gumbi PP, Nkwanyana NN, Bere A, et al. Impact of mucosal inflammation on cervical HIV-specific CD8 T-cell responses in the female genital tract during chronic HIV infection. J Virol 2008;82(17):8529-8536. [http://dx.doi.org/10.1128/JVI.00183-08]

37. Zara F, Nappi RE, Brerra R, Migliavacca R, Maserati R, Spinillo A. Markers of local immunity in cervicovaginal secretions of HIV-infected women: Implications for HIV shedding. Sex Transm Infect 2004;80(2):108-112. [http://dx.doi.org/10.1136/ sti.2003.005157]

38. Beigi RH, Meyn LA, Moore DM, Krohn MA, Hillier SL. Vaginal yeast colonization in nonpregnant women: A longitudinal study. Obstet Gynecol 2004;104(5):926930. [http://dx.doi.org/10.1097/01.AOG.0000140687.51048.73] 